\title{
PRECIPITINS AGAINST EXTRACTS OF HAY AND MOULDS IN THE SERUM OF PATIENTS WITH FARMER'S LUNG, ASPERGILLOSIS, ASTHMA, AND SARCOIDOSIS
}

\author{
BY
}

\author{
J. PEPYS*, R. W. RIDDELL, K. M. CITRON, AND Y. M. CLAYTON \\ From the Institute of Diseases of the Chest, and Brompton Hospital, London
}

The pulmonary disorder known as farmer's or thresher's lung, due to the inhalation of the dust from mouldy hay, was first described in Britain by Campbell (1932), and subsequently by Fawcitt (1936, 1938a), Fuller (1953), Studdert (1953), Williams and Mulhall (1956), and elsewhere by Dickie and Rankin (1958), Frank (1958), Totten, Reid, Davis, and Moran (1958), and Baldus and Peter (1960). The disorder is widely distributed throughout the United Kingdom and appears to be more common than was previously suspected (Staines and Forman, 1961). A similar disorder due to other cereal dusts, such as straw, grain, and bagasse, has been reported by Fawcitt (1938b), Törnell (1946), Fuller (1953), Dickie and Rankin (1958), Castleden and Hamilton-Paterson (1942), and Buechner, Prevatt, Thompson, and Blitz (1958). The clinical picture consists of an acute pyrexial reaction with cough and dyspnoea, appearing some hours after exposure to the dust. Subacute and chronic phases of the disorder have been described by Fuller (1953). The pathological changes found in biopsy and necropsy material consist of a granulomatous infiltration of the interstitial tissues, which results in fibrosis and emphysema in the late stages (Fuller, 1953; Dickie and Rankin, 1958 ; Frank, 1958).

The production of the symptoms has been attributed to mechanical irritation, to fungal infection, and to hypersensitivity to the fungi in the dust. The increasing severity of reactions to the dust with repeated exposure suggests that hypersensitivity is important. The absence of asthma and rhinitis in subjects suffering from farmer's lung indicates that immediate type hypersensitivity mediated by non-precipitating antibody is not present, and this is further borne out by the absence of specific sensitivity in skin tests with extracts of hay, dust, and the fungi in mouldy hay (Törnell, 1946; Studdert, 1953 ; Frank, 1958 ; and Fuller, 1953).

\footnotetext{
* Member of the Research Group in Clinical Immunology, Medical Research Council.
}

So-called "good" hay contains a wide variety of fungal genera, including Aspergillus, Cladosporium, Penicillium, Mucor, and Humicola as well as actinomycetes and bacteria. These are found in greater amount in so-called " mouldy" hay, which results from the storage of good hay with too high a content of moisture. The demonstration of precipitating antibody against aspergillus extracts in the serum of patients with the hypersensitive type of bronchopulmonary aspergillosis due to Aspergillus fumigatus by Pepys, Riddell, Citron, Clayton, and Short (1959) led to a similar investigation for precipitins in patients suffering from farmer's lung, particularly since $A$. fumigatus is commonly found in both good and mouldy hay.

\section{Materials AND Methods}

TeST SERA.-The following sera were tested.

Farmer's Lung Sera (Group 1).--Initial and detailed investigations were made in group 1a which consisted of sera provided by Dr. C. J. Fuller from ten patients in the West of England with a definite clinical diagnosis.

In group $1 \mathrm{~b}$ were 61 sera provided from patients in whom a diagnosis of farmer's lung had been made by various physicians in widely separated parts of Britain and Ireland.

Aspergillosis Sera (Group 2).-Thirty sera containing precipitins against $A$. fumigatus were obtained from patients with the hypersensitive type of bronchopulmonary aspergillosis, as described by Pepys and others (1959), namely, patients with asthma, transitory pulmonary infiltrations, eosinophilia in the peripheral blood, and positive skin test reactions to aspergillus extracts.

Control Sera (Group 3).-Group 3a contained sera from 59 farmers provided by the same physicians who submitted sera from the patients in groups 1a and $1 \mathrm{~b}$. The diagnosis of farmer's lung was not made in these subjects, 16 being normal and the remainder having asthma, bronchitis, or other disorders. These sera were investigated as controls for the patients with farmer's lung because of their 
similar exposure to the mouldy hay dusts which had provoked symptoms in the affected patients.

Group $3 \mathrm{~b}$ consisted of 20 sera submitted to the Brompton Hospital pathology laboratories for routine investigation such as blood grouping.

Group 3c was 50 pairs of normal maternal and cord blood sera.

Group 3d was 11 rabbit sera.

Group 3e contained sera from 90 patients with asthma or bronchitis.

Sarcoidosis Sera (Group 4).-A group of 50 sera provided by Drs. N. Wynn-Williams and J. H. Baylis, of Bedford, from patients with sarcoidosis were tested against extracts of mouldy hay and fungi. These tests were performed because of the similarity in the radiographic appearances of the miliary nodular infiltration of the lungs in sarcoidosis and in farmer's lung and because of the similarity of the histological appearances of the granulomatous lesions.

TEST EXTRACTS.-Specimens of nine mouldy hays which were known to have been responsible for the production of symptoms in the patients in group 1a were extracted. The hays were placed in separate Kilner jars and acetone was added. After standing overnight the acetone was decanted and $0.5 \%$ carbol saline (Coca's solution) added in the proportion of $10 \% \mathrm{w} / \mathrm{v}$. After standing at room temperature for five days the extracting fluid was removed, Seitzfiltered, dialysed overnight against running tap-water, and then freeze-dried. A concentration of 10 to $20 \mathrm{mg} . / \mathrm{ml}$. of the freeze-dried extract was employed for agar-gel diffusion tests.

Two specimens of good hay were provided by Dr. P. H. Gregory, of the Rothamsted Experimental Station, and were extracted in the same way as the mouldy hay. Extracts of the first specimen, good hay (1), contained antigens like those of Cladosporium herbarum, and the second, good hay (2), like those of Mucor (sp.).

Samples of the good hay (1) were placed in Kilner jars before and after autoclaving for 15 minutes at 15 lb. pressure. Heavy inocula of Mucor (sp.) and A. fumigatus respectively were added, and, after standing for two weeks, the inoculated hays were extracted.

A freeze-dried carbol saline extract of the fine dust of mouldy hay containing predominantly actinomycetes and bacteria was employed for testing at 10 to $20 \mathrm{mg} . / \mathrm{ml}$.

The cell-sap of the mycelia and the culture filtrates of four to eight-week-old cultures of $A$. fumigatus, C. herbarum, Humicola lanuginosa, and Mucor (sp.) on Sabouraud's glucose-peptone broth were employed for the preparation of the test antigens. The extracts were Seitz-filtered, dialysed and freeze-dried, and then prepared in solution at 20 to $30 \mathrm{mg} . / \mathrm{ml}$.

Method of Testing.-Agar-gel tests were performed by the Ouchterlony method (1953). Inhibition tests were performed by adding extracts of the hays and fungi to the sera to give a concentration of $10 \mathrm{mg}$. of freeze-dried extract in $1 \mathrm{ml}$. of serum. The various extracts were then tested against the absorbed sera to see whether or not the precipitation reactions were altered.

\section{RESULTS}

\section{Precipitation Reactions}

FARMER'S LUNG SERA (Group 1).--Reactions of the sera in group 1a to extracts of mouldy hays are shown in Table I. All 10 of the sera from the patients with farmer's lung gave precipitation reactions with one or more of the nine extracts ; one serum (no. 10) reacted with only one of the extracts. The extracts of mouldy hay also varied

TABLE I

PRECIPITATION REACTIONS BETWEEN SERA FROM 10 PATIENTS WITH FARMER'S LUNG AND EXTRACTS OF NINE MOULDY HAYS

\begin{tabular}{cc}
$\begin{array}{c}\text { Mouldy } \\
\text { Hay } \\
\begin{array}{c}\text { Extract } \\
\text { No. }\end{array}\end{array}$ & $\begin{array}{c}\text { No. of Sera } \\
\text { Giving } \\
\text { Precipitation } \\
\text { Reactions }\end{array}$ \\
\hline 1 & 9 \\
2 & 9 \\
3 & 9 \\
4 & 7 \\
5 & 7 \\
6 & 4 \\
7 & 3 \\
8 & 3 \\
9 & 2
\end{tabular}

\begin{tabular}{cc}
$\begin{array}{c}\text { Serum } \\
\text { No. }\end{array}$ & $\begin{array}{c}\text { No. of Extracts } \\
\text { Giving } \\
\text { Precipitation } \\
\text { Reactions }\end{array}$ \\
\hline 1 & 9 \\
2 & 9 \\
3 & 7 \\
4 & 6 \\
5 & 6 \\
6 & 5 \\
7 & 5 \\
8 & 3 \\
9 & 2 \\
10 & 1
\end{tabular}

in the number of sera with which they reacted; extracts nos. 1, 2, and 3 reacted with nine of the sera, though not with the same sera in each case, whilst one extract (no. 9) reacted with only two sera. Thus extracts from more than one specimen of mouldy hay were needed to produce reactions with all of the 10 sera tested.

Of the 61 sera in group $1 \mathrm{~b}$ from patients in whom the diagnosis of farmer's lung had been made, 50 reacted to extracts of mouldy hay. Of the remaining 11 patients, in six the disorder followed exposure to the dust of corn, and another patient had had the disorder many years previously. These patients were not tested with extracts of the cereal or mouldy hay dust which were actually responsible for their symptoms.

In the total group of 60 subjects whose sera contained precipitins against mouldy hay, two were female, their ages ranged from 18 to 68 years, the duration of the disease from five months to 25 years, and about $45 \%$ had acute disease, $10 \%$ subacute, and $45 \%$ chronic disease.

Of the total of 60 subjects in groups $1 \mathrm{a}$ and $1 \mathrm{~b}$ with precipitins against mouldy hay extracts, $50 \%$ had precipitins against good hay, $25 \%$ against $\boldsymbol{A}$. fumigatus, $16 \%$ against $C$. herbarum, $6 \%$ against Penicillium notatum, 52\% against Mucor (sp.), 
TABLE II

PRECIPITATION REACTIONS IN AGAR-GEL TESTS TO EXTRACTS OF HAY AND FUNGI

\begin{tabular}{|c|c|c|c|c|c|c|c|c|c|}
\hline \multirow[b]{2}{*}{ Serum Group } & \multirow[b]{2}{*}{$\begin{array}{l}\text { No. of } \\
\text { Patients }\end{array}$} & \multicolumn{8}{|c|}{ Percentage of Reactions to Extracts of the Following: } \\
\hline & & $\begin{array}{l}\text { Mouldy } \\
\text { Hay }\end{array}$ & $\begin{array}{l}\text { Good } \\
\text { Hay (1) }\end{array}$ & $\begin{array}{l}\text { A. fumi- } \\
\text { gatus }\end{array}$ & $\begin{array}{l}\text { C. her- } \\
\text { barum }\end{array}$ & $\underset{\text { notatum }}{P .}$ & $\begin{array}{l}\text { Mucor } \\
\text { (sp.) }\end{array}$ & $\begin{array}{l}\text { Humicola } \\
\text { lanuginosa }\end{array}$ & $\begin{array}{l}\text { Actinomyc } \\
\text { and Bacte }\end{array}$ \\
\hline $\begin{array}{l}\text { 1. Farmer's lung } \\
\text { With precipitins } \\
\text { to mouldy hay } \\
\text { 1a-10 } \\
\text { 1b-50 }\end{array}$ & & & & & & & & & \\
\hline $\begin{array}{l}\text { Without precipitins } \\
\text { to mouldy hay }\end{array}$ & 60 & 100 & 50 & 25 & 16 & 6 & 52 & 11 & 18 \\
\hline $\begin{array}{l}\text { 1b-11 } \\
\text { 2. Aspergillosis } \\
\text { 3. Controls }\end{array}$ & $\begin{array}{l}11 \\
30\end{array}$ & $\begin{array}{r}0 \\
80\end{array}$ & $\begin{array}{r}0 \\
70\end{array}$ & $\begin{array}{r}0 \\
100\end{array}$ & $\begin{array}{r}\mathbf{0} \\
\mathbf{3 3}\end{array}$ & $\begin{array}{r}0 \\
10\end{array}$ & $\begin{array}{r}9 \\
10\end{array}$ & $\begin{array}{l}\mathbf{0} \\
\mathbf{0}\end{array}$ & $\begin{array}{l}\mathbf{0} \\
\mathbf{0}\end{array}$ \\
\hline a. Farmers & $\begin{array}{l}59 \\
20\end{array}$ & $\begin{array}{l}\mathbf{0} \\
\mathbf{0}\end{array}$ & $\begin{array}{l}4 \\
0\end{array}$ & $\begin{array}{l}8 \\
0\end{array}$ & $\begin{array}{l}\mathbf{0} \\
\mathbf{0}\end{array}$ & $\begin{array}{l}\mathbf{0} \\
\mathbf{0}\end{array}$ & $\begin{array}{l}\mathbf{0} \\
\mathbf{0}\end{array}$ & $\begin{array}{l}4 \\
0\end{array}$ & $\begin{array}{l}\mathbf{0} \\
\mathbf{0}\end{array}$ \\
\hline $\begin{array}{l}\text { cord blood } \\
\text { d. Rabbit }\end{array}$ & $\begin{array}{r}100 \\
11\end{array}$ & $\begin{array}{l}7 \\
0\end{array}$ & $\begin{array}{l}\mathbf{0} \\
\mathbf{0}\end{array}$ & $\begin{array}{l}\mathbf{0} \\
\mathbf{0}\end{array}$ & $\begin{array}{l}\mathbf{0} \\
\mathbf{0}\end{array}$ & $\begin{array}{l}\mathbf{0} \\
\mathbf{0}\end{array}$ & $\begin{array}{l}0 \\
0\end{array}$ & $\begin{array}{l}0 \\
0\end{array}$ & $\begin{array}{l}\mathbf{0} \\
\mathbf{0}\end{array}$ \\
\hline $\begin{array}{l}\text { bronchitis } \\
\text { 4. Sarcoidosis }\end{array}$ & $\begin{array}{l}90 \\
50\end{array}$ & $\begin{array}{l}12 \\
32\end{array}$ & $\begin{array}{l}7 \cdot 5 \\
0\end{array}$ & $\begin{array}{l}5 \\
0\end{array}$ & $\begin{array}{l}1 \\
0\end{array}$ & $\underline{2}^{2 \cdot 5}$ & $\begin{array}{l}5 \\
2\end{array}$ & $\begin{array}{l}0 \\
0\end{array}$ & $\underline{0}$ \\
\hline
\end{tabular}

$11 \%$ against Humicola lanuginosa, and $18 \%$ against an extract of the fine fraction of the dust of mouldy hay, containing bacteria and actinomycetes (Table II).

The mouldy hay extracts produced multiple, sharply defined precipitation lines. Some of these fused with lines produced in adjacent tests by extracts of both mouldy and good hay, showing the presence of related antigenic components in the mouldy and good hays. Related antigenic components were also demonstrable in the extracts of $C$. herbarum and good hay in particular, and also in $C$. herbarum and mouldy hay. The similarity between the extracts of $C$. herbarum and good hay (1) was marked and was supported by the inhibition tests which are to be described. The extract of good hay (2) contained antigens like those of Mucor (sp.), and this is well illustrated in Figure 1.

Whilst the extracts of the different mouldy hays had antigenic components in common, there were also distinctive antigens in the individual extracts. The precipitation reactions showed that there were multiple antigenic components in mouldy hay, that not all of these were present in any one of the extracts, and that the patients tended to have different patterns of antibodies. This would explain why extracts of more than one specimen of mouldy hay were required in order to produce reactions with the sera from most of the proven cases and possibly why no reactions were obtained in 11 of the sera in group $1 b$.

Aspergillosis Sera (Group 2).-In tests on 10 sera with extracts of the nine mouldy hays (Table III) precipitation lines with one or more of the mouldy hay extracts were obtained in seven, though in no case with more than six extracts. Similarly, the mouldy hay extracts reacted with

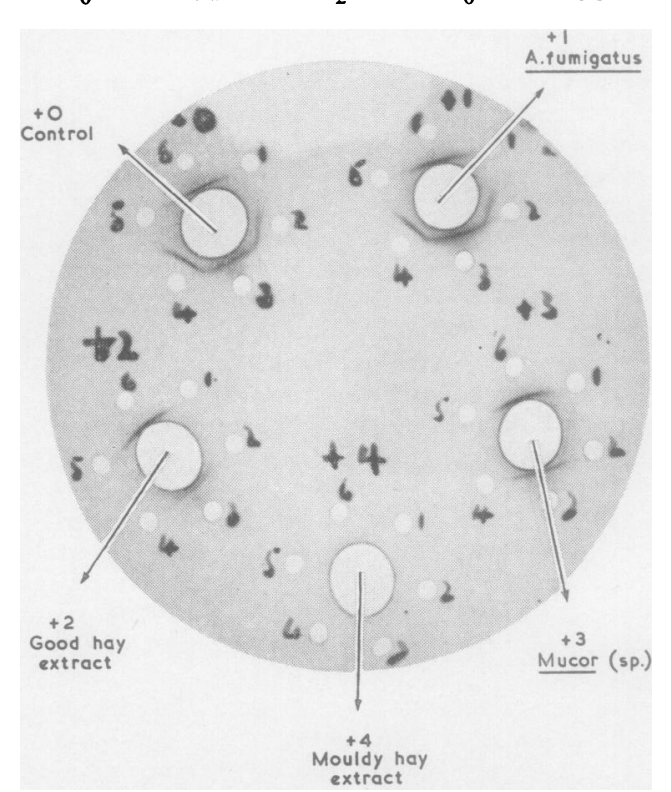

FIG. 1. Inhibition tests. Farmer's lung serum is in central well and following test extracts in peripheral wells : 1, A. fumigatus (Czapek-Dox culture) ; 2, good hay (2); 3, mouldy hay (1); 4, Mucor (sp.); 5, A. fumigatus (Sabouraud culture); and 6, mouldy hay (2). Note: Precipitation reactions to extracts of good hay (2), mouldy hay (1), Mucor (sp.), and mouldy hay (2) ; no reactions to extracts of $\mathrm{A}$. fumigatus.

Addition to serum in central well of extract of: (+1) A. fumigatus produced no effect; $(+2)$ good hay (2) produced inhibition of reactions to extract of good hay, of Mucor (sp.), and of one precipitation line of mouldy hay (1); (+3) Mucor (sp.) produced inhibition of reaction of Mucor ( $s p$.), partial inhibition of reactions of good hay, and inhibition of one precipitation line of mouldy hay: and $(+4)$ mouldy hay produced complete inhibition of good hay, Mucor (sp.), and mouldy hay reactions. 
TABLE III

PRECIPITATION REACTIONS BETWEEN SERA FROM 10 PATIENTS WITH BRONCHOPULMONARY ASPERGILLOSIS AND EXTRACTS OF NINE MOULDY HAYS

\begin{tabular}{cc}
$\begin{array}{c}\text { Mouldy } \\
\text { Hay } \\
\text { Extract } \\
\text { No. }\end{array}$ & $\begin{array}{c}\text { No. of Sera } \\
\text { Giving } \\
\text { Precipitation } \\
\text { Reactions }\end{array}$ \\
\hline 1 & 7 \\
2 & 7 \\
3 & 7 \\
4 & 6 \\
5 & 5 \\
6 & 5 \\
7 & 1 \\
8 & 0 \\
9 & 0
\end{tabular}

\begin{tabular}{cc}
$\begin{array}{c}\text { Serum } \\
\text { No. }\end{array}$ & $\begin{array}{c}\text { No. of Extracts } \\
\text { Giving } \\
\text { Precipitation } \\
\text { Reactions }\end{array}$ \\
\hline 1 & 6 \\
2 & 6 \\
3 & 6 \\
4 & 6 \\
5 & 5 \\
6 & 5 \\
7 & 3 \\
8 & 1 \\
9 & 0 \\
10 & 0
\end{tabular}

fewer of the aspergillosis than of the farmer's lung sera.

Of the total group of 30 patients whose sera contained aspergillus precipitins, $80 \%$ had precipitins against mouldy hay, $70 \%$ against good hay (1), $33 \%$ against $C$. herbarum, $10 \%$ against $P$. notatum, $10 \%$ against Mucor (sp.), and none against Humicola lanuginosa or actinomycetes and bacteria from mouldy hay (Table II).

The above findings show that sera from patients with farmer's lung and with aspergillosis contain antibodies against the same extracts, i.e., of good hay, mouldy hay, and the various fungi (Table II). The most marked differences are the small percentage of reactions (25\%) to $A$. fumigatus and the high percentage of reactions to Mucor (sp.) with the farmer's lung sera. Inhibition tests which were performed served to distinguish between the two groups of sera.

Control Sera (Group 3).-No precipitins were found against the hay extracts in the 59 control sera from farmers (group 3a). Precipitins against $A$. fumigatus were found in five of the sera.

No precipitins were found in the 20 routine sera (group 3b).

Precipitins against extracts of mouldy hay only were found in $7 \%$ of the normal maternal and cord blood sera (group 3c).

No precipitins were found in the rabbit sera (group 3d).

Precipitation reactions against extracts of mouldy hay were found in the sera of 11 $(12 \%)$ of the 90 patients with asthma and bronchitis (group 3e). These reactions were weak and inconstant and appeared after four or five days in contrast to the reactions with the farmer's lung and aspergillosis sera which appeared within 24 or 48 hours. Reactions to the extract of good hay (1) appeared in three $(7.5 \%)$ of the 40 sera, and there were from 1 to $5 \%$ of reactions to the other fungi (Table II).
SARCoIDOSIS SERA (Group 4).-Precipitation reactions against one of four extracts of mouldy hay were found in $16(32 \%)$ out of the 50 sera from patients with sarcoidosis. Of the 16 sera, only two reacted to two of the four extracts tested, and all the sera gave a single precipitation line. Reactions to the extract of Mucor (sp.) occurred in one $(2 \%)$ of the 50 sera, and there were no reactions to the extracts of good hay, of $A$. fumigatus, or of $C$. herbarum (Table II).

\section{INHIBITION TESTS}

FARMER's LuNG SERA.-The inhibition tests showed that the addition of the extracts of the fungi and of good hay to the farmer's lung sera could prevent the appearance of precipitation reactions on subsequent testing with these extracts but had little or no effect on the reactions to the extracts of mouldy hay. These could only be inhibited effectively by the addition of mouldy hay extracts to the sera. These findings are evident in Table IV (Figure 1).

TABLE IV

INHIBITION TESTS IN FARMER'S LUNG SERA

\begin{tabular}{|c|c|c|c|c|c|c|}
\hline \multirow{3}{*}{$\begin{array}{ll}\text { Extract } & \text { P } \\
\text { Added } & - \\
\text { to } & \\
\text { Serum } & \\
& \boldsymbol{g}\end{array}$} & \multicolumn{6}{|c|}{$\begin{array}{c}\text { Precipitation Lines Produced by the Following Extracts } \\
\text { were Inhibited }\end{array}$} \\
\hline & \multirow{2}{*}{$\begin{array}{l}\text { A. } \\
\text { fumi- } \\
\text { gatus }\end{array}$} & \multirow{2}{*}{$\begin{array}{c}\text { C. } \\
\text { her- } \\
\text { barum }\end{array}$} & \multirow{2}{*}{$\begin{array}{c}\text { Good } \\
\text { Hay } \\
\text { (1) }\end{array}$} & \multicolumn{3}{|c|}{ Mouldy Hay } \\
\hline & & & & 1 & 2 & 3 \\
\hline A. fumigatus & $3 / 3$ & $1 / 1$ & $\begin{array}{c}3 / 5 \\
2 \text { partial }\end{array}$ & $\begin{array}{c}18 \\
\text { partial }\end{array}$ & $\begin{array}{c}18 \\
\text { partial }\end{array}$ & 02 \\
\hline C. herbarum & 33 & $4 / 5$ & $\begin{array}{c}6 / 8 \\
2 \text { partial }\end{array}$ & 111 & 011 & 05 \\
\hline Good hay (1) & $3 / 3$ & $4 / 4$ & $8 / 8$ & $\underset{\text { partial }}{2: 11}$ & $\begin{array}{c}211 \\
\text { partial }\end{array}$ & $\begin{array}{c}1 / 5 \\
\text { partial }\end{array}$ \\
\hline $\begin{array}{l}\text { Mouldy hay } \\
\text { (1) } \\
\text { Mucor (sp.) } \\
\text { Humicola }\end{array}$ & $3 / 3$ & $5: 5$ & $7 / 7$ & $\begin{array}{l}11 / 11 \\
1 \text { partial } \\
0 / 9\end{array}$ & $\begin{array}{l}11 / 11 \\
3 \text { partial } \\
0,4\end{array}$ & 55 \\
\hline $\begin{array}{l}\text { lanuginosa } \\
P \text {. notatum } \\
\text { Actinomycete } \\
\text { and bacter } \\
\text { fraction of } \\
\text { mouldy hay }\end{array}$ & $\begin{array}{l}\text { e } \\
\text { ial } \\
y\end{array}$ & & & $\begin{array}{c}0 / 4 \\
0 / 4 \\
3 / 4 \\
\text { v. slight } \\
\text { inhibition }\end{array}$ & $\begin{array}{c}0 / 4 \\
0 / 4 \\
3 / 4 \\
\text { v. slight } \\
\text { inhibition }\end{array}$ & $\begin{array}{c}0 / 4 \\
0 / 4 \\
3 / 4 \\
\text { v. slight } \\
\text { inhibition }\end{array}$ \\
\hline
\end{tabular}

The addition of $A$. fumigatus extract to the sera inhibited the production of precipitation lines when the absorbed sera were tested with extracts of $A$. fumigatus and $C$. herbarum and partially inhibited the reactions to the good hay extract. It produced little inhibitory effect on the precipitation reactions of three mouldy hay extracts.

The addition of $C$. herbarum extract to the sera inhibited the reactions of the $A$. fumigatus and $C$. herbarum tests and of most of the tests with the good hay extracts. It had little or no effect on the precipitation reactions of the mouldy hay extracts.

The addition of the extract of good hay to the sera produced an inhibitory effect very similar to 
that of $C$. herbarum except that it was more effective in inhibiting its own precipitation reactions with all the sera. This extract too had little inhibitory effect on the mouldy hay extract reactions.

The addition of extracts of Humicola lanuginosa, Mucor (sp.), and P. notatum had no inhibitory effect on the mouldy hay extract reactions. The addition of the extract of the fine dust fraction of mouldy hay, consisting predominantly of actinomycetes and bacteria, produced only a slight weakening of the precipitation lines of the mouldy hay extracts.

The addition of a potent mouldy hay extract effectively inhibited all the precipitation lines produced by $A$. fumigatus, $C$. herbarum, good hay, and notably those produced by the mouldy hay extracts themselves. The mouldy hay extracts, therefore, contain not only fungal antigens but also additional antigens against which the antibodies appear to be chiefly directed.

Aspergillosis SERA.-The inhibition tests with the aspergillosis sera show, in marked contrast to the farmer's lung sera, that the addition of extracts of the fungi and of good hay inhibited reactions not only to further tests with themselves but also the reactions to the mouldy hay extracts. This is evident from Table V.

TABLE V

INHIBITION TESTS IN ASPERGILLOSIS SERA

\begin{tabular}{|c|c|c|c|c|c|}
\hline \multirow{3}{*}{$\begin{array}{l}\text { Extract } \\
\text { Added } \\
\text { to } \\
\text { Serum }\end{array}$} & \multicolumn{5}{|c|}{$\begin{array}{l}\text { Precipitation Lines Produced by the Following } \\
\text { Extracts were Inhibited }\end{array}$} \\
\hline & \multirow{2}{*}{$\begin{array}{c}\text { A. fumi- } \\
\text { gatus }\end{array}$} & \multirow{2}{*}{$\begin{array}{l}\text { C. her- } \\
\text { barum }\end{array}$} & \multirow{2}{*}{$\begin{array}{c}\text { Good } \\
\text { Hay (1) }\end{array}$} & \multicolumn{2}{|c|}{ Mouldy Hay } \\
\hline & & & & 1 & 2 \\
\hline $\begin{array}{l}\text { A. fumigatus } \\
\text { C. herbarum }\end{array}$ & $\begin{array}{c}4 / 4 \\
7 / 8 \\
3 \text { partial }\end{array}$ & $\begin{array}{l}3 / 3 \\
7 / 7\end{array}$ & $\begin{array}{l}4 / 4 \\
8 / 8\end{array}$ & $\begin{array}{l}1 / 4 \\
8 / 8\end{array}$ & $\begin{array}{l}0 / 2 \\
6 / 6\end{array}$ \\
\hline Good hay (1) & 4/8 & $7 / 7$ & $8 / 8$ & $8 / 8$ & $6 / 6$ \\
\hline Mouldy hay & $\begin{array}{c}4 / 8 \\
3 \text { partial }\end{array}$ & 77 & $\begin{array}{c}8 / 8 \\
1 \text { partial }\end{array}$ & $8: 8$ & 66 \\
\hline
\end{tabular}

The addition of $A$. fumigatus extract to the sera inhibited the precipitation lines produced with the unabsorbed sera by the extracts of $A$. fumigatus, $C$. herbarum, and good hay, and to a lesser extent the reactions produced by extracts of two mouldy hays.

The addition of extracts of $C$. herbarum and of good hay respectively produced a similar result. Both produced a partial inhibition of the precipitation lines of $A$. fumigatus, the $C$. herbarum extract being the more effective. Both, however, effectively inhibited the precipitation reactions of the mouldy hay extracts with all the sera.

The addition of the mouldy hay extract to the sera produced limited and partial inhibition of the
$A$. fumigatus reaction. It effectively inhibited with all the sera the precipitation lines of $C$. herbarum, of good hay, and of the two mouldy hay extracts tested.

Thus there is an important difference between the inhibitory effects of $C$. herbarum and of good hay extracts on the farmer's lung and on the aspergillosis sera. The extracts of $C$. herbarum and of good hay had very little effect on the reaction of mouldy hay extracts with farmer's lung sera, whilst they inhibited the reactions of the mouldy hay extracts with the aspergillosis sera. This difference indicates that it is the fungal component of mouldy hay which is reacting with the aspergillosis sera, whereas the wider range of reactions with farmer's lung sera are due to additional antigens in it for which antibodies are present only in these sera and not in the aspergillosis sera. The previous report (Pepys and others, 1959) of related antigens in $A$. fumigatus and $C$. herbarum is confirmed by the findings of inhibition tests in both the farmer's lung and aspergillosis sera. These suggest that it is the $C$. herbarumlike component of $A$. fumigatus which is reacting with the farmer's lung sera, since the addition of extracts of $C$. herbarum and of good hay (1) to the sera inhibited the $A$. fumigatus reactions completely. This component of the $A$. fumigatus extract seems to be a "minor" one, since high concentrations of extract were needed to produce the reactions. The presence of "major" components of the A. fumigatus extract, more specific for aspergillosis sera, is suggested by the finding that neither the extract of $C$. herbarum nor that of good hay (1) in particular produced more than partial inhibition of the $A$. fumigatus extract reactions with these sera.

REACTIONS TO EXTRACTS OF GoOd Hay (1) BEFORE AND AFTER INOCUlation WITH Moulds (TABLe VI)

FARMER'S LUNG SERA.-The extract of good hay gave a precipitation reaction with four of the farmer's lung sera, whereas the extract from the good hay after inoculation with Mucor (sp.) and

TABLE VI

AGAR-GEL TESTS WITH EXTRACTS OF GOOD HAY (1), A. FUMIGATUS, AND C. HERBARUM

\begin{tabular}{ccc}
$\begin{array}{c}\text { Extract } \\
\text { (10 mg./ml.) }\end{array}$ & $\begin{array}{c}\text { 10 Farmer's Lung } \\
\text { Sera } \\
\text { (No. Positive) }\end{array}$ & $\begin{array}{c}10 \text { Aspergillosis } \\
\text { Sera } \\
\text { (No. Positive) }\end{array}$ \\
\hline $\begin{array}{c}\text { Good hay (1) } \\
\text { plus Mucor (sp.) }\end{array}$ & 4 & 7 \\
A. fumigatus & 3 & 1 \\
Autoclaved good hay (1) & 1 & 1 \\
plus Mucor (sp.) & 3 & 7 \\
A. fumigatus & 6 & 7 \\
A. fumigatus & 6 & 6 \\
C. herbarum & 3 & 10 \\
& 3 & 5
\end{tabular}


A. fumigatus respectively reacted with fewer sera, three with the first and one with the latter.

The extract of good hay which had been autoclaved reacted with three sera, whereas the extract of the autoclaved hay after inoculation with Mucor (sp.) and $A$. fumigatus gave reactions with more sera, six in each case. This suggests that the autoclaving had in some way enhanced the capacity of the fungi to produce reacting antigens from the hay.

ASPERgILlosis SERA.-The extract of good hay, after inoculation with Mucor (sp.) and $A$. fumigatus respectively, showed a marked decrease in the number of reactions with the aspergillosis sera, from seven to one out of 10 in each case. This decreased reactivity was similar to, but more marked than, that which was found with this material on testing with the farmer's lung sera. On the other hand, inoculation of autoclaved good hay with Mucor (sp.) and $A$. fumigatus did not alter the reactivity of the extracts for aspergillosis sera, whereas it increased the number of reactions produced with the farmer's lung sera, thus showing that additional antigens had been produced for this latter group of sera.

\section{Discussion}

The presence of precipitins in the serum of patients with farmer's lung reported here is the first evidence in this disorder of antibodies against antigens which are present in mouldy hay. The findings suggest that the precipitins are directed not only against certain of the mould flora of the hay but also, and perhaps more particularly, against products of the hay itself. This conclusion is supported by a comparison of the findings, with the same extracts of the hays and the moulds, in tests on the sera of patients with farmer's lung and with the hypersensitive type of bronchopulmonary aspergillosis.

Both the farmer's lung and the aspergillosis sera contained precipitins against extracts of mouldy hay, good hay, and $C$. herbarum. Precipitins were also present against high concentrations of $A$. fumigatus in a quarter of the farmer's lung sera, whereas all the aspergillosis sera contained precipitins against lower concentrations. The reactions of both groups of sera showed a close antigenic relationship between extracts of $C$. herbarum and of good hay, these antigens being present also in mouldy hay. The extracts of mouldy hay, however, contained additional antigens for which antibodies were present in the farmer's lung sera but not in the aspergillosis sera. It seems unlikely that the other extracts tested, of $A$. fumigatus, Mucor (sp.), Humicola lanuginosa, $\boldsymbol{P}$. notatum, or of the actinomycete and bacterial fraction of mouldy hay, are responsible for these additional antigens of the mouldy hay extract. These extracts, except for the Mucor (sp.), reacted infrequently with the farmer's lung sera and showed, on addition to the farmer's lung sera, little or no inhibiting effect on the reactions of the mouldy hay extracts with these sera.

An important contrast was shown with the aspergillosis sera. It was found that the antigens in the extracts of $C$. herbarum and of good hay were closely related to those in the extracts of mouldy hay which reacted with these sera. The addition of either $C$. herbarum extract or good hay extract to the sera inhibited all the reactions of the mouldy hay extract. There was, therefore, no evidence of the presence in aspergillosis sera of antibodies against the additional antigens of the mouldy hay extracts. The addition of the extract of $A$. fumigatus itself to the sera had only a partial inhibitory effect on the reactions with the mouldy hay extracts, and the addition of these latter in turn to the sera had only a partial inhibitory effect on the reactions of the $A$. fumigatus extract. In a previous report (Pepys and others, 1959) and in the present investigation, related antigens were found in the extracts of $C$. herbarum and of $A$. fumigatus. It seems that it is the $C$. herbarum-like component of $A$. fumigatus which is responsible for the reactions of the $A$. fumigatus extract with the farmer's lung sera, and for the reactions of some of the mouldy hay extracts with the aspergillosis sera.

Exposure to good hay does not as a rule excite the farmer's lung reaction, and extracts of good hay react with only about one half of the farmer's lung sera. In order to try to produce mouldy hay type antigens in good hay, the good hay was inoculated with Mucor (sp.) and $A$. fumigatus respectively before and after having been autoclaved. The extracts of the non-autoclaved good hay after inoculation with these fungi showed a reduced antigenicity for the farmer's lung sera and in particular for the aspergillosis sera. By contrast, the extracts of good hay, which had been autoclaved first and then inoculated with the fungi, reacted with more farmer's lung sera than the autoclaved good hay which had not been inoculated with the fungi, and than the extracts of non-autoclaved hay. In the natural course of production of mouldy hay overheating is an important feature. This, together with the above 
findings, suggests that the additional antigens of mouldy hay may be produced by the combination of the action of moulds and heat. A striking similarity is to be found in bagassosis, in which exposure to clean, "good" bagasse is innocuous, whereas inhalation of the dust from mouldy bagasse, which undergoes an increase in temperature in the process, excites pulmonary manifestations like those in farmer's lung (Buechner and others, 1958). The changes which take place in vegetable dusts after becoming mouldy under appropriate conditions seem to liberate substances which are highly antigenic for man and animals.

The role of the moulds in the production of the disease may be secondary in that, whilst they increase the antigenicity of the hay, there is other evidence to suggest that they do not themselves provoke the clinical picture of farmer's lung. Hypersensitivity to fungi such as $C$. herbarum and $A$. fumigatus is commonly of the immediate type, mediated by non-precipitating antibody and leading to rhinitis and asthma, wealing reactions on skin testing, and asthma on inhalation testing. Hypersensitivity to $A$. fumigatus in asthmatic subjects may also be associated with pulmonary eosinophilia, and in these patients precipitating antibodies to $A$. fumigatus and $C$. herbarum may be found (Pepys and others, 1959 ; Pepys, 1960). These manifestations do not occur in farmer's lung, in which asthma and rhinitis and wealing reaction on skin testing with extracts of moulds and hays are not present. Furthermore, Williams (1961) has found that inhalation and skin tests with extracts of good hay, autoclaved good hay, and the moulds described above did not provoke reactions in the patients with farmer's lung in group 1a of this report, whereas inhalation tests with extracts of mouldy hay excited a febrile pulmonary reaction coming on several hours afterwards. This reaction was considered by the patients to be similar to that excited by exposure to mouldy hay in the past. These findings correspond well with the precipitin tests which showed the presence in mouldy hay extracts not only of fungal antigens but of additional antigens, and suggest that it is these additional antigens which are responsible for the pulmonary reaction.

A remarkably similar pattern of reactions has been found by Parish (1961, and to be published) in rabbits and guinea-pigs which were exposed to mouldy hay and its dusts. It was found that the sensitized animals reacted only to extracts of, or to exposure to, mouldy hay and not to the extracts of the mould flora of the hay. The pulmonary reactions of the animals resembled those in patients with farmer's lung, being most evident some hours after exposure, and were not of the anaphylactic type. Only those animals with precipitins against mouldy hay gave these reactions.

The inconstant reactions of mouldy hay extracts with the serum of the asthmatic and bronchitic subjects were not comparable with those produced in the sera from patients with farmer's lung or aspergillosis, and they reacted only infrequently with the other fungal extracts.

Although there is good evidence of a relationship between the antigens of mouldy hay and the precipitins against them in the production of farmer's lung, the finding of precipitins against mouldy hay in the serum of patients with sarcoidosis shows that the serological findings cannot distinguish between sarcoidosis and all cases of farmer's lung. The sarcoidosis sera did not react to $A$. fumigatus, and only one out of 50 reacted to Mucor (sp.). It seems, therefore, that the antibodies against the extracts of mouldy hay, which were demonstrated in the sarcoidosis and in the asthmatic sera, resulted from exposure to one or a limited number of the complex of antigens in mouldy hay, probably arising from some other commonly encountered material in the environment. The sarcoid subjects in this investigation, whose sera reacted to mouldy hay, had not had contact with mouldy hay as far as is known. The significance of their precipitins is obscure, and it remains to be seen whether they are due to enhanced production of antibody by the increased amount of reticulo-endothelial tissue in the granulomata of sarcoidosis or whether they are related to the production of the granulomata.

In evaluating the serological findings described above, it is clear that they have a limited value for diagnostic purposes, the clinical features taking precedence at all times. It has been shown that mouldy hays vary in their antigenic components, and it is probable that mouldy cereal dusts will also differ. This would explain the negative reactions to extracts of mouldy hay in 11 out of 71 sera from patients in whom the diagnosis of farmer's lung was made. A negative reaction does not exclude the diagnosis in a patient with clinical and perhaps radiographic evidence of the disorder.

Certain points of distinction are, however, to be found in the serological tests:

1. In those instances where the serum contains precipitins against mouldy hay, and also against A. fumigatus, $C$. herbarum, and Mucor (sp.), the 
possibility of either farmer's lung or aspergillosis has to be considered since reactions to all these extracts were obtained with these two groups only. The distinguishing feature here is the capacity of extracts of $C$. herbarum and of Mucor (sp.), on addition to aspergillosis sera, to inhibit the reactions of these sera with mouldy hay extracts. They have, on the other hand, little or no inhibitory effect on the reactions of farmer's lung sera to mouldy hay extracts.

2. Where the serum reacts to extracts of mouldy hay and of Mucor (sp.) but not to those of $A$. fumigatus or of $C$. herbarum, the diagnosis of farmer's lung is suggested, and this could apply at most to that half of the farmer's lung sera tested which were found to contain precipitins against Mucor (sp.). The absence of precipitins against aspergillus extracts would make aspergillosis unlikely. The sera from the asthmatic and bronchitic group and from the sarcoidosis group reacted very infrequently, or not at all, with $\boldsymbol{A}$. fumigatus or Mucor (sp.). Pulmonary infection with $\boldsymbol{A}$. fumigatus in a patient with sarcoidosis would, of course, alter the situation since precipitins against this fungus would be very likely to appear, and under these circumstances inhibition tests could be expected to give the same results as the aspergillosis sera described above.

3. Sera which react to mouldy hay extracts only could come from at least half the patients with farmer's lung or from patients with sarcoidosis, asthma, bronchitis, or apparently normal subjects. There is no serological evidence at present to help to distinguish between these groups, hence the emphasis on the clinical picture.

The histological appearances in farmer's lung consist of an infiltration of the interstitial tissue with epithelioid and giant cell granulomata of a sarcoid type. This, too, differs from the infiltration with eosinophil cells which occurs in immediate anaphylactic type hypersensitivity reactions, such as pollen hypersensitivity, and from the lymphoid cell granuloma which is a feature of the delayed tuberculin type of hypersensitivity.

There is evidence to suggest that the formation of sarcoid-like granulomata is a response to particulate material such as large amounts of silica particles in non-sensitive subjects (Shelley and Hurley, 1961) and antigen-antibody aggregates in hypersensitive subjects (Germuth, 1961). Whilst part of the tissue reaction in farmer's lung is probably due to foreign body reaction, the possibility that the precipitins described may be combining with the antigens of mouldy hay, thereby providing antigen-antibody aggregates, should be considered. In hypersensitive subjects small doses of the specific antigen provoke the granulomatous reaction (Shelley and Hurley, 1961), and it is well known in farmer's lung that hypersensitive subjects cannot tolerate even small amounts of mouldy hay dust, whereas nonsensitive subjects are not obviously affected by massive doses.

It is not possible at this stage to decide whether the precipitins in the farmer's lung sera are evidence only of exposure to the dust of mouldy hay, which contains a wide range of substances which are potently antigenic for man, or whether they are participating in the production of the pathological changes. Should they be found to be playing an active role, the evidence would point to participation of a product of the hay, probably resulting from the action of the fungi, as the cause of the condition.

\section{SUMmaRY}

Precipitins against extracts of mouldy hay, good hay, and of the fungal and other flora of mouldy hay were found in agar-gel tests with the sera of patients suffering from farmer's lung and from bronchopulmonary aspergillosis. The farmer's lung sera contained precipitins not only against some of the fungi present in the hay but also, and in particular, against substances derived from the mouldy hay itself, whereas the aspergillosis sera contained precipitins only against the fungal components of mouldy hay and of good hay.

Of 71 patients with farmer's lung, 60 had precipitins against mouldy hay ; and in these sera precipitins were present against good hay in $50 \%$, $A$. fumigatus in $25 \%, C$. herbarum in $16 \%, P$. notatum in $6 \%$, Mucor (sp.) in $52 \%$, Humicola lanuginosa in $11 \%$, and actinomycetes and bacteria in $18 \%$. The aspergillosis sera contained precipitins against mouldy hay in $80 \%$, good hay in $70 \%, C$. herbarum in $33 \%, P$. notatum in $10 \%$, Mucor (sp.) in 10\%, and none against Humicola lanuginosa and the actinomycetes and bacteria.

Inhibition tests showed that the reactions to mouldy hay extracts of the farmer's lung sera could only be inhibited by extracts of mouldy hay and not by extracts of the fungi or of good hay. The reactions of mouldy hay extracts with the aspergillosis sera were inhibited by extracts of the fungi and of good hay. The evidence suggests that the additional antigens in mouldy hay are produced by the action of the fungi on heated hay and that these additional antigens are responsible for the disorder. 
Precipitins against extracts of mouldy hay only were found in the sera of $32 \%$ of patients with sarcoidosis, irregularly in $12 \%$ of patients with asthma and bronchitis, and in $7 \%$ of normal maternal and cord blood sera. The sarcoidosis sera did not react to extracts of good hay or of the fungi tested, and the asthmatic sera reacted infrequently.

The serological findings suggest that reactions to extracts of mouldy hay, $A$. fumigatus, and Mucor (sp.) could occur in both farmer's lung and aspergillosis, but these conditions could be distinguished by inhibition tests. Reactions to mouldy hay and Mucor (sp.) would suggest farmer's lung, whilst reactions solely to mouldy hay could occur in farmer's lung, sarcoidosis, and asthma or bronchitis.

The authors wish to thank Dr. C. J. Fuller for his invaluable co-operation in providing the clinical and other materials on which the initial studies were based, and the clinicians who, having participated in the survey of farmer's lung by the College of General Practitioners, provided sera for examination. Our thanks are due to Dr. P. H. Gregory for providing samples of hay, to Drs. N. Wynn-Williams and J. H. Baylis for a supply of sera from patients with sarcoidosis, and to Dr. J. G. Scadding for providing clinical facilities and for his guidance and advice throughout the investigation.

\section{REFERENCES}

Baldus, W. P., and Peter, J. B. (1960). New Engl. J. Med., 262, 700. Buechner, H. A., Prevatt, A. L., Thompson, J., and Blitz, O. (1958). Amer. J. Med., 25, 234.

Campbell, J. M. (1932). Brit. med. J., 2, 1143.

Castleden, L. I. M., and Hamilton-Paterson, J. L. (1942). Ibid., 2, 478.

Dickie, H. A., and Rankin, J. (1958). J. Amer. med. Ass., 167, 1069. Fawcitt, R. (1936). Brit. J. Radiol., 9, 172.

- (1938a). Ibid., 11, 378.

- (1938b). Amer. J. Roentgenol., 39, 19.

Frank, R. C. (1958). Ibid., 79, 189.

Fuller, C. J. (1953). Thorax, 8, 59.

Germuth, F. G. (1961). Amer. Rev. resp. Dis., 84, No. 5, part 2, p. 84 (Proc. Int. Conf. on Sarcoidosis, 1960).

Ouchterlony, ö. (1953). Acta path. microbiol. scand., 32, 231.

Farish, W. E. (1961). Acta allerg. (Kbh.), 16, 78.

Pepys, J. (1960). Acta allerg. (Kbh.), suppl. 7, p. 108. Riddell, R. W., Citron, Y. M., Clayton, Y. M., and Short, E. I. (1959). Amer. Rev. resp. Dis., 80, 167.

Shelley, W. B., and Hurley, H. J. (1961). Amer. Rev. resp. Dis., 84, No. 5, part 2, p. 45 . (Proc. int. Conf. on Sarcoidosis, 1960).

Staines, F. H., and Forman, J. A. S. (1961). J. Coll. gen. Practit., 4, 351.

Studdert, T. C. (1953). Brit. med. J., 1, 1305.

Törnell, E. (1946). Acta med. scand., 125, 191.

Totten, R. S., Reid, D. H. S., Davis, H. D., and Moran, T. J. (1958). Amer. J. Med., 25, 803.

Williams, D. I., and Mulhall, P. P. (1956). Brit. med. J., 2, 1216. Williams, J. V. (1961). Acta allerg. (Kbh.), 16, 77. 